\title{
MODELLING OF EMISSIONS FROM LARGE BIOGAS PLANTS
}

\author{
MODELOWANIE EMISJI Z DUŻYCH BIOGAZOWNI
}

\begin{abstract}
The main objective of the "Guidelines for the development of agricultural biogas plants in Poland within 2010-2020", is a construction of biogas plants processing agricultural biomass resources with suitable conditions in each municipality. In the Czech Republic produces about $6.5 \%$ of energy from renewable sources. Biogas plants give - contrary to solar and wind electricity stations - the stable performance throughout the whole year. Biomass should be a key source for achieving the Czech EU commitment to produce 13\% of energy from renewable sources in 2020. The experience, where 317 Agricultural biogas plants are currently in operation, has shown that there are considerable problems with a proper location of newly designed agricultural biogas plants in the landscape. The Czech-Polish border area is mainly flat wooded recreation region. For these reasons, the Gaussian model SYMOS'97 (version 2013), adapted for odour dispersion modelling from large agricultural sources is supposed to be suitable for this area. It is appropriate for training of students. For these reasons, students from the University of Hradec Kralove and the University of Opole in the frame of their academic exchange and professional internships are acquainted with the technological principles of biogas plants and in environmental mathematical and statistical modelling of the spread of emissions from large industrial and agricultural sources. In this article we present methods for education on these professional areas.
\end{abstract}

Keywords: biogas, odour, SYMOS'97

\section{Introduction}

The first documented experiments using biogas in Europe were carried out by Leonardo da Vinci and Van Helmont who used biogas to generate light. English physicist Faraday also experimented with biogas. Italian physicist A. Volta is considered to be the discoverer of controlled anaerobic fermentation operating laboratory anaerobic digester for

\footnotetext{
${ }^{1}$ Department of Physics, University of Hradec Králové, Rokitanského 62, 50003 Hradec Králové, Czech Republic, phone +420 721806230, email: jan.kriz@uhk.czm

${ }^{2}$ EMPLA Za Škodovkou 305/5, 50311 Hradec Králové, Czech Republic

${ }^{3}$ Czech Hydrometeorological Institute, Na Šabatce 2050/17, 143 06 Praha, Czech Republic

${ }^{4}$ IDEA-ENVI Valašské Meziříčí, Havlíčkova 234/1, 75701 Valašské Meziříčí, Czech Republic

${ }^{5}$ Independent Chair of Biotechnology and Molecular Biology, Opole University, ul. kard. B. Kominka 6, 45-032 Opole, Poland

*Corresponding author: jan.kriz@uhk.cz
} 
biogas combustion in 1776. Use of biogas from wastewater treatment plants for water heating was mentioned in a hospital in Bombay in 1897.

In 1922, the wastewater treatment plant in Essen allegedly handed biogas into town gasworks. Adjusted biogas as a fuel began to be exploited in 1937 in Germany, Italy and France. Efforts to use biogas in Europe ceased with the onset of the development of the oil industry. In China, India and other developing countries, several million very simple family of agricultural biogas plants are operating that use biogas from organic waste are faeces for lighting and heating. In Germany operates more than 3500 biogas plants, especially of municipal types. In Sweden, biogas is also used to power vehicles the first train in the world powered by biogas was opened there. In Denmark, a biogas plants consist of a centralized system with the collection of bioorganic waste [2].

Anaerobic methane fermentation of organic substances, known as methanisation, is a set of processes in which the mixed culture of microorganisms gradually, without access of air, decomposes the biodegradable organic matter. This is a set of several individual, successive processes which involve several basic groups of anaerobic microorganisms. Product of a single group of microorganisms becomes a substrate of the downstream. Therefore, a loss of one group may cause disturbances in the whole system. According to the current concept, the process is realised in four phases, hydrolysis, acidogenesis, acetogenesis and methanogenesis. Hydrolysis is the first step of degradation of polymeric compounds (polysaccharides, proteins and fats) to basic monomer components by using extracellular enzymes facultatively anaerobic bacteria. Acidogenesis follows, ie phase of the organic acids formation, in which the monomers of the same bacteria action change into lower fatty acids (short chains), alcohols, hydrogen and carbon dioxide. During the last phase, called methanogenesis, methane and carbon dioxide are formed from acetic acid by the reaction with obligate anaerobic microorganisms [3].

Methane arises from the anaerobic fermentation in the narrow range of $\mathrm{pH}$ being 6.5-8.5 (with the optimum at $\mathrm{pH} 7-8$ ). For agricultural substrates, especially cattle slurry is responsible for buffering properties. Under these conditions, $\mathrm{pH}$ is no more representative parameter of the fermented material.

The retention time of the substrate indicates the time of substrate staying in the fermenter. It must be chosen so that no greater amount of methanogenic microorganisms would be removed from the reactor with the output material compared with that grown in the same period or that delivered in a new substrate [4].

Economically, the most suitable residence time corresponds to $75 \%$ removal of organic compounds. Considerably higher dose of substrate material is required at a shorter residence time in the reactor (30-40 days) in comparison with a long one (60-70 days) with the aim to achieve the same efficiency [5].

The so-called biology status indicators characterize course of sub-processes or the entire courses of anaerobic fermentation. For example, coenzyme $\mathrm{F}_{420}$ can be monitored in the liquid phase. It is a unique coenzyme occurring only in methanogenic microorganisms, which participates in the reduction of $\mathrm{CO}_{2}$ to $\mathrm{CH}_{4}$. Coenzyme $\mathrm{F}_{420}$ exhibits strong fluorescence at the excitation wavelength of $420 \mathrm{~nm}$. Methodology has been developed for fluorescence determination of coenzyme $F_{420}$ in anaerobic sludge and in agricultural substrates. Interpretation of these results is not easy, because coenzyme $F_{420}$ produce fluorescence only in the reduced form and its content varies according to the type of microorganism. Relative concentration changes of this coenzyme during monitoring 
a certain type of anaerobic biomass are very closely connected to the activity of methanogens and the process conditions and they give valuable pieces of information [6].

Methane is under normal conditions gaseous substance slightly lighter than air, so its transport in the atmosphere can be basically unlimited. Since it is almost insoluble in water, it is not substantially removed from the air even by rainfall (global exposure).

The ability of the methane molecules to absorb infrared radiation escaping from the Earth's surface (the greenhouse effect), is estimated to be ca 23 times stronger than that of carbon dioxide. However, it has a relatively short persistence in the atmosphere, about 12 years. It has been demonstrated that methane is involved in degradation of stratospheric ozone. Therefore, there is not only an effort to avoid methane free escape into the atmosphere, however, there is a strong tendency to utilise it effectively and in a targeted manner [7].

The biogas plant is a technological device which processes biomass (waste materials of organic origin) through fermentation controlled anaerobic digestion in reactors called fermenters. The term anaerobic digestion is increasingly used in the technology of biogas plants. Controlled anaerobic digestion is environmentally promising way of using biomass, organic waste and energy crops, respectively.

The product of anaerobic digestion is called digestate, which is the solid residue after fester, called fugat, liquid residue after digestion, and biogas, used for energy formation purposes. Digestate can serve as a good fertilizer. Fugat, having character of waste water, is usually discharged into the sewage.

Controlled anaerobic digestion process requires the provision of appropriate life conditions for microorganisms. The basic premise is anaerobic environment (without air) with sufficient humidity (at least $50 \%$ ), $\mathrm{pH}$ optimum (6.5 to 7.5 ) and a constant temperature (usually $38^{\circ} \mathrm{C}$ ).

The optimum temperature for anaerobic digestion is associated with different strains of bacteria. Mezophilic area (about $37^{\circ} \mathrm{C}$ ), which is most often used for the lower energy consumption and thermophilic one (about $55^{\circ} \mathrm{C}$ ) permits a relatively large streamlining processes, but is considerably more energy demanding.

Conditions for success of anaerobic digestion consist in prevention of inhibitors access (oxygen, low $\mathrm{pH}$, bactericidal drugs, heavy metals).

Biomass is heated to operating temperature in an anaerobic reactor, called fermentor or in an anaerobic digester where it remains for a fixed time called retention time.

Biogas constitutes mixture of gases $\left(\mathrm{CH}_{4} 45-75 \%\right.$ carbon dioxide $\mathrm{CO}_{2} 25-55 \%$, $\mathrm{H}_{2} \mathrm{O} 2-7 \%$ water $\left(40^{\circ} \mathrm{C}\right)$ sulfane $\mathrm{H}_{2} \mathrm{~S}<3 \% \mathrm{~N}_{2}<5 \%$ oxygen $\mathrm{O}_{2}<3 \%$ hydrogen $\mathrm{H}_{2}<1 \%$ ).

$\mathrm{H}_{2} \mathrm{~S}$ is an undesirable component of biogas (suppliers of biogas gensets usually tolerate sulphur content up to $500 \mathrm{mg} \mathrm{H}_{2} \mathrm{~S} \cdot \mathrm{m}^{-3}$ ). Biogas can easily be desulphurised by the direct microaerophilically controlled air supply oxidation in the reactor or in a gas holder. Its calorific value is in the interval from 18 to $26 \mathrm{MJ} / \mathrm{m}^{3}$, depending on the methane content. $\left(100 \% \mathrm{CH}_{4}\right.$ has a calorific value of $35.8 \mathrm{MJ} / \mathrm{m}^{3}$, biogas $55 \% \mathrm{CH}_{4}$ is $19.7 \mathrm{MJ} / \mathrm{m}^{3}$, natural gas has $33.5 \mathrm{MJ} / \mathrm{m}^{3}$ ). The explosive concentrations in air are $5-15 \%$.

The produced biogas is conducted into a tank and adjusted for further use. It can be directly burned in the boiler when the resulting heat can be used for heating buildings, hot water production, etc. [3].

Cogeneration is referred to a combined production of heat and electrical energy. The facilities where the combined production of heat and electricity are carried out are called 
cogeneration units (biomotors). Electrical energy (about 35\%) is produced by spinning the electric generator by means of a combustion engine. The heat released in the combustion engine is effectively retrieved from the engine cooling system, oil and fumes with $90 \%$ efficiency.

Industrial biogas plants elaborate risk inputs in the digesters, for example abattoir waste, sludge from various operations, eg wastewater treatment plants, etc. Great demands are placed on hygiene rules. Contravention of technological processes results in formation of inadequate odour from waste around industrial biogas plants [2, 4].

Agricultural biogas plants are conceptually simpler than other biogas plants. Their input consists of farmyard products (slurry, manure) and energy crops such as corn. Their plant construction takes place directly in the premises of agricultural farms.

\section{Biogas plant Agrodruzstvo Lhota}

Agricultural biogas plant Agrodruzstvo Lhota pod Libcany near from Hradec Kralove was built in 2010. One of the goals of the project was to solve the waste materials that could be the source of groundwater contamination. The whole area is, in terms of groundwater protection, classified as endangered. In addition to deliberately cultivated crops (corn, rye, grass, alfalfa) and beet pulp, as waste from the food industry is processed and environmentally problematic manure from cows (Fig. 1).

The total installed electric capacity of the BPS makes $600 \mathrm{~kW}$ and $608 \mathrm{~kW}$ of heat.

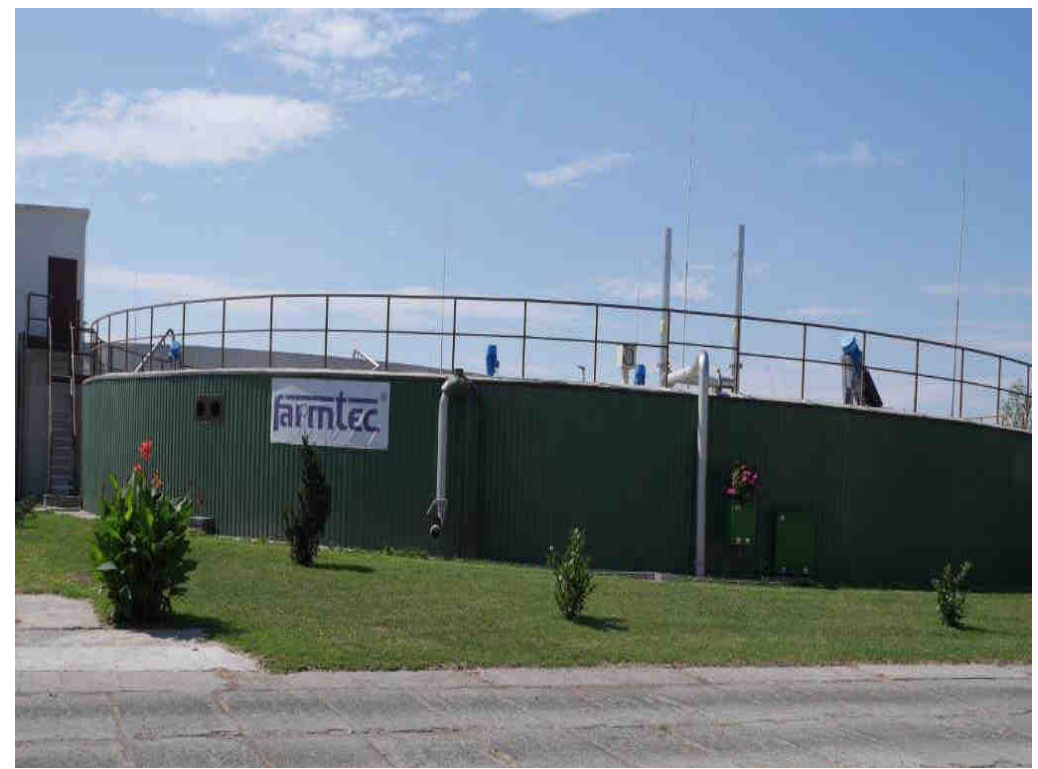

Fig. 1. Agricultural Biogas plant Agrodruzstvo Lhota pod Libcany, fermenter two-type "ring ring"

In Figure 2 a cogeneration unit for this station is shown. The heat from October to April is consumed mainly for heating the entire area and from May to December the biggest consumer of heat is belt drier of agricultural crops. 


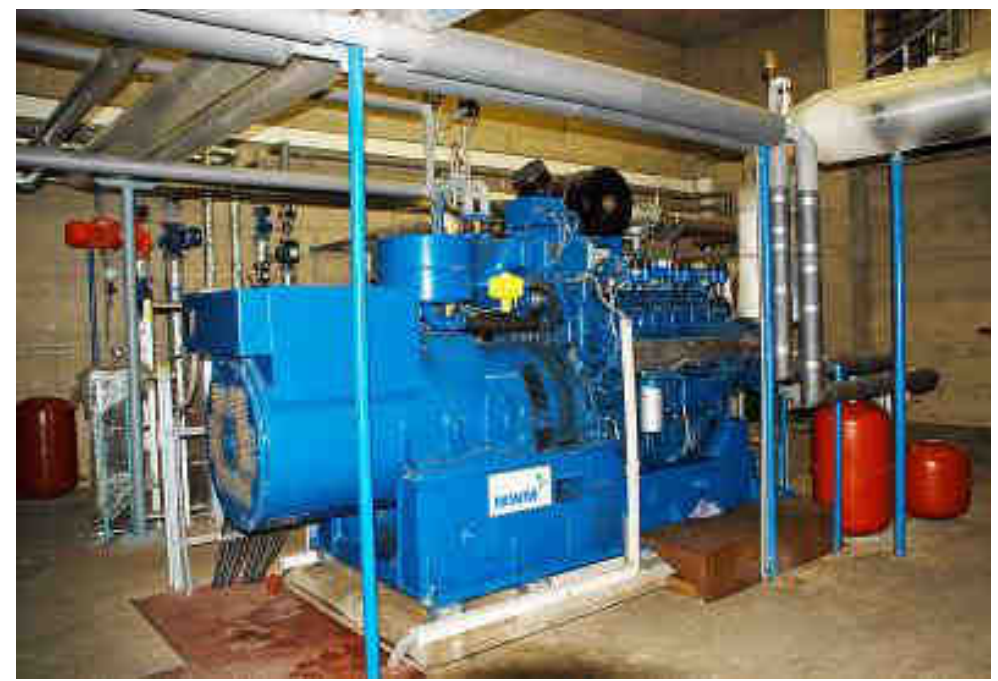

Fig. 2. Agricultural Biogas Cogeneration unit Agricultural Biogas plant Agrodruzstvo Lhota pod Libcany

Managing system of a modern biogas station contains a central programmable controller with remote input-output modules on the bus. It enables efficient and economical management of the biogas plant, in order to achieve maximum utilization of input materials (silage, haylage, manure) and ensured smooth performance. Technological switchboards are usually located close to the technology in an extension in front of fermenters.

A touchscreen panel for local control is placed on one of the switchgears. Required feedstock is metered by a metering screw apparatus and it is pumped into the fermentation tank using a screw pump. This device is controlled by frequency converters and connected to the system. The diluted material is stirred in the fermentation tank with the aim to achieve a greater homogeneity.

The tank is simultaneously heated, the heat being taken form the cogeneration unit. If it is a two-stage anaerobic process, it contains so called primary and secondary digesters. Biogas from all fermenters is collected in a central bag. The produced biogas is subsequently compressed, dried and burned in a cogeneration unit.

Functions of the management machine allow automatic dispensing of raw materials. Blockage and correct opening scuff guards for the transportation of raw materials and direct traffic between raw fermenters are checked and controlled. It checks the correctness of open scuff in the pipeline. It automatically ventilates the pipe from a developed gas and manages the process of mixing in fermenters depending on the density of raw materials. It monitors the start-up of mixers, so that overloading the power supply would not exist. It controls the collection, storage and processing of biogas. It completely monitors the technological process of biogas stations, and monitors the operational status of the cogeneration unit and controls auxiliary operations (ventilation, circulation pumps, heating of fermenters and objects). It sends a warning SMS and email messages to the operator in case of a failure and limit states. 
Function of operator station allows a complete monitoring of system. It records and graphically displays important operational data and allows one to preview the state of technology biogas plant through a web interface. The second operator workstation consists of a touch panel.

Pressure measurement - it is based mostly on direct measurement of the pressure in the various circuits of technology and it serves as a protection of the pumps. Used sensors have flush diaphragm for measurement of liquids with higher viscosity.

Temperature measurement - direct temperature measurement is performed inside the anaerobic digesters and in the room of cogeneration, also the temperature of the cavity pumps is monitored in order not to damage them. RTD thermometers are used with integrated converter without display.

Level measurement - the measurements are used to detect levels in sumps. Limit types or continuous types are used, vibrating level switch with contact output being used for limit ones. Continuous level measurement (contactless) is chosen in cases where the measured medium could clog the measuring sensor or where its location would be installation-complex. Radar and ultrasonic sensors are used for these measurements.

Flow measurement - added liquid component are measured being used for optimization of biology process in the anaerobic digesters. Magnetic flowmeter is proposed as a measuring sensor.

It is necessary to ensure optimal $\mathrm{pH}$ (6.5 to 7.5$)$ for optimal fermentation process with the aim to achieve maximum yield. Continuous regulator of $\mathrm{pH}$ converter can reliably drive dosing pumps so that the optimal $\mathrm{pH}$ would be achieved. Two-channel version of the two controllers for the simultaneous control of two fermenters may be advantageously used for these applications. The transducer for measuring $\mathrm{pH}$ is equipped with external calibration mode simplifying calibration procedure.

Biogas analyser BC 20 BIOGEST UK installed at the Agricultural Biogas plant Lhota pod Libcany (Fig. 3) are in continuous operation and records the actual values. Principle sensory measurement of methane and carbon dioxide utilises a thermal conductivity sensor which determines the mixing ratio of both gases based on their different thermal conductivity.

Other gases are measured using an electrochemical principle. The analyser is designed so that it has two inputs, one for continuous analysis and another for periodic measurements.

Continuously concentrations of methane, carbon dioxide and oxygen are determined. Periodically are determined sulfane, hydrogen and carbon monoxide. Methane gas concentration, carbon dioxide and oxygen instantaneous values are recalculated from measured values from biogas. The processed values are transported to a data interface and also to a data logger archiving measured and recalculated data.

Biogas analyser stations of a new generation typically operate on the principle of Infra Gas Filter Correlation IR GFC, $\lambda_{\mathrm{CH} 4}=4.66 \mu \mathrm{m}$. For example, biogas analyser AIR LF produced by ASEKO allows the measurement of the concentration of six components of biogas, infrared methods of measurement is used for $\mathrm{CH}_{4}$ and $\mathrm{CO}_{2}$, and the electrochemical measurement for $\mathrm{O}_{2}, \mathrm{H}_{2} \mathrm{~S}, \mathrm{H}_{2}$ and $\mathrm{NH}_{3}$.

Monitoring system of the biogas plant Lhota pod Libcany records and graphically displays important operational data and allows users to search on the state of technology biogas plant through a web interface. 
In Figure 4 an example of a function of monitoring station is shown. The system monitors the course of the technological process and it sends warning SMS and e-mail messages to the operator in case of a failure and limit states.

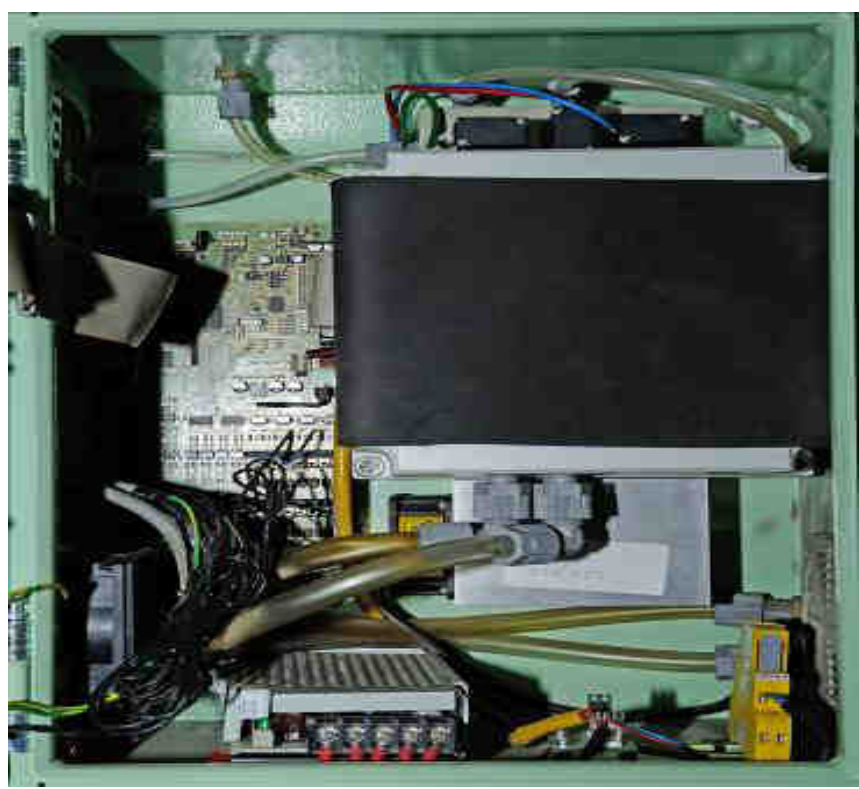

Fig. 3. Inside view of biogas analyser BC 20 fy BIOGEST UK. Agricultural Biogas plant Agrodruzstvo Lhota pod Libcany

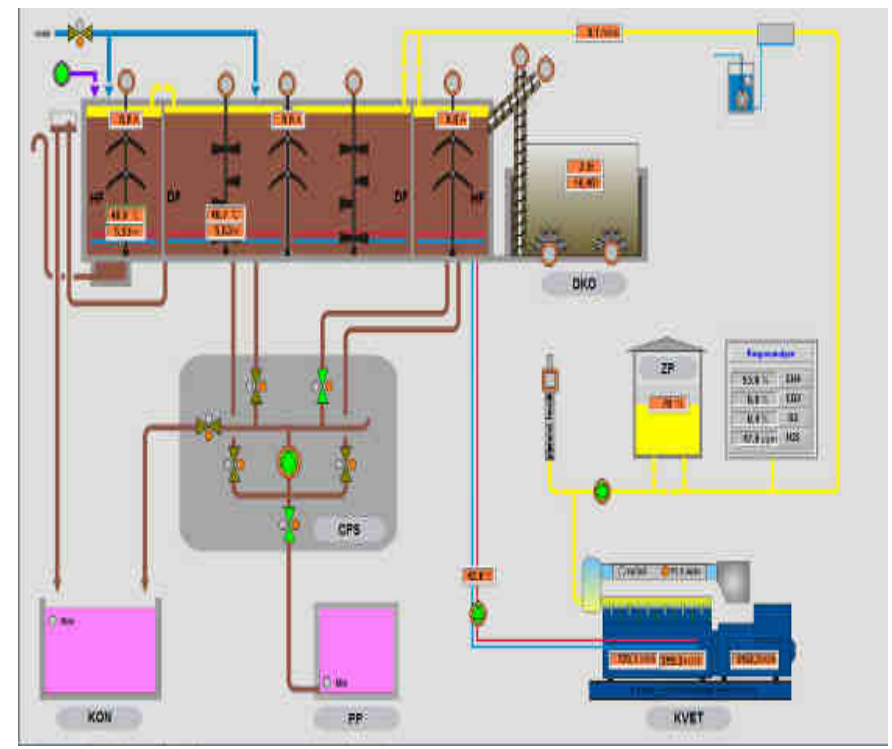

Fig. 4. An example of functions of monitoring station installed at the Agricultural Biogas plant Lhota pod Libcany 
Even a short-term exposure of human beings to high concentrations of methane can lead to suffocation due to lack of oxygen. Risk associated with the occurrence and use of methane is in its explosion being mixed with air (5-15\%).

Security systems in biogas plants are arranged on step-by-step principles. Security keys are located on the compartment door and risky places of technology. Total stop button is located in the cogeneration building and switches off the entire operation of the biogas plants from supply and backup supply. Detectors of methane concentration are also introduced into the system that switch ventilation and alert the operator at the first level of methane concentration. At the second level of methane concentration, they stop all activities in biogas plant in such a way so that they exclude all sources of initialization of methane explosion. Emergency stop button located in the cogeneration building disconnects all equipment including cogeneration unit, but the main supply remains unchanged.

Buttons located on the technological switchboards and those in hazardous locations disconnect only technological equipment, cogeneration unit is capable of normal operation. Equipment designed for milling of raw material (macerators) are equipped with safety limit switches which block the run when the device is open.

Each larger biogas plant should be able to use a reserve energy source - a diesel generator. In the case of a prolonged power stoppage, important facilities are started in a controlled manner so that not to interrupt biological processes and to be able to re-establish standard operation procedure.

The cost of building a biogas plant is about 40 to 50 million Czech Crowns (CZK). Farmers can draw on them subsidies, they can reach up to $40 \%$ of the price to build the station. Payback period is from 10 to 12 years.

\section{Odour dispersion modelling}

The experience from the Czech Republic has shown that there are considerable problems with a proper location of newly designed agricultural biogas plants in the landscape. We introduced the possibility of use of the SYMOS'97 dispersion model (version 2013) adapted for odour dispersion modelling.

It is well known and documented in the literature that the odour subjective perception by humans is proportional to the instantaneous peak concentration of the odorant rather than to mean values. Because the SYMOS model [8], similarly as other dispersion models of this class, is set for calculation of hourly mean concentrations, the basic procedure how to modify these for odour concentration consisted in recalculation of hourly means reached in particular hours into corresponding peak values which might occur during these hours. Widely used peak-to-mean ratio (P/M ratio) approach has been selected as suitable solution of this task and incorporated into model [9].

General basic equation for calculating the concentration of pollutant gases exhaled from stationary sources in the hilly terrain assuming a Gaussian distribution concentration in siding has the form: 


$$
\begin{gathered}
c=\frac{10^{6} \cdot M_{z}}{2 \cdot \pi \cdot\left(\sigma_{y}+\sigma_{y 0}\right) \cdot\left(\sigma_{z}+\sigma_{z 0}\right) \cdot u_{h 1}+V_{s}} \cdot \exp \left(\frac{-y_{L}^{2}}{2\left(\sigma_{y}+\sigma_{y 0}\right)^{2}}\right) \cdot \exp \left(-k_{u} \cdot \frac{x_{L}}{u_{h 1}}\right) \cdot K_{h} . \\
\cdot\left[\exp \left(-\frac{\left(z^{\prime}-h_{1}\right)^{2}}{2\left(\sigma_{z}+\sigma_{z 0}\right)^{2}}\right)+(1-\vartheta) \cdot \exp \left(-\frac{\left(z^{\prime \prime}+h_{1}\right)^{2}}{2\left(\sigma_{z}+\sigma_{z 0}\right)^{2}}\right)+\vartheta \cdot \exp \left(-\frac{\left(z^{\prime \prime \prime}-h_{1}\right)^{2}}{2\left(\sigma_{z}+\sigma_{z 0}\right)^{2}}\right)\right]
\end{gathered}
$$

where: $c$ - concentration of emission, $M_{z}$ - mass flow of the pollutant per unit time from one surface element, $V_{s}$ - volume flow of emissions, $k_{u}, K_{h}$ - option fallout.

Five hydrometeorological stability classes by Czech national stability scheme applied within the model [9].

Czech reference model SYMOS'97, adapted for odour dispersion modelling [10] works with the relationship:

$$
I_{o d}=k\left(C_{o d}\right)^{n}
$$

where: $I_{o d}$ - odour intensity, $C_{o d}$ - modelled odour concentration, $k, n$ - constants for a stink odour

for odor dispersion from agricultural sources [10] works with the relationship:

$$
I_{o d}=1.086\left(C_{o d}\right)^{0.464}
$$

Odour subjective perception by humans proportional to the instantaneous peak concentration of the odorant rather than to mean values. SYMOS'97 model, similarly like other dispersion models of this class, is set for calculation of hourly mean concentrations. The basic procedure how to modify the SYMOS for odour concentration comprises recalculation of hourly means reached in particular hours into corresponding peak values which might occur during these hours. Widely used is peak-to-mean ratio (P/M ratio) [11].

\section{Conclusions}

The Czech-Polish border area is mainly flat wooded recreation region. For these reasons [1], the Gaussian model of odour dispersion from agricultural sources is supposed to be suitable for this area. It is appropriate for training students. This work continues with the participation of students from the University of Opole and the University of Hradec Kralove in the frame of their academic exchange and professional internships in EMPLA AG Hradec Kralove CZ and in IDEA-ENVI Valasske Mezirici CZ.

\section{References}

[1] Bioplynove stanice v Polsku - Energeticka politika Polska do roku 2030. http://www.coach-bioenergy.eu/cs/projektnovinky/politika-novinky/222-energy-polica-poland-2030.html, accessed 10.10.2015.

[2] Raven RPJM, Gregersen KH. Biogas plants in Denmark: successes and setbacks. Renew Sust Energy Rev. 2007;11(1):116-32. DOI: 10.1016/j.rser.2004.12.002.

[3] Ferry JG. The chemical biology of methanogenesis. Planet Space Sci. 2010;58(14-15):1775-83. DOI: 10.1016/j.pss.2010.08.014.

[4] Manyi-Loh CE, Mamphweli SN, Meyer EL, Okoh AI, Makaka G, Simon M. Microbial anaerobic digestion (bio-digesters) as an approach to the decontamination of animal wastes in pollution control and the generation of renewable energy. Int $J$ Environ Res Public Health. 2013;10(9):4390-417. DOI: 10.3390/ijerph10094390. 
[5] Somayaji D, Khanna S. Biomethanation of rice and wheat straw. World J Microbiol Biotechnol. 1994;10(5):521-523.

[6] Zabranska J, Schneiderova K, Dohanyos M. Relation of coenzyme $\mathrm{F}_{420}$ to the activity of methanogenic microorganisms. Biotech Lett. 1985;7:547-552. link.springer.com/article/10.1007\%2FBF01026443, accessed 12.10.2015.

[7] Cicerone RJ. Biogeochemical aspects of atmospheric methane. Global Biogeochem Cycles. 1988;2(4):299-327. https://webfiles.uci.edu/setrumbo/public/Methane_papers/Cicerone_Global\%20 Biogeochem\%20Cy_1988, accessed 10.11.2015.

[8] Eminger S, Stepanek V, Hetfleis M, Smolik M, Hysplerova L, Kriz J. The planned development of the agricultural biogas plants on the Czech-Polish border region, possibility of using of three-dimensional models of methanation process. In: Kłos A, Wacławek M, editors. Propagowanie badań jakości środowiska na transgranicznym obszarze polsko-czeskim. (Propagation of research on environment quality of Polish-Czech cross-border area). Opole: Basnet; 2014:218-230.

[9] Keder J, Macoun J, Manak J. SYMOS’97 - Stationary Sources Modelling System - a reference manual (in Czech), Prague: CHMI; 1998. http://www.chmi.cz/uoco/prj/model/index.html, accessed 11.11.2015.

[10] Keder J, Bubnik J, Macoun J. Validation of Czech Model SYMOS'97 adapted for odour dispersion modelling and its validation. Meteorological J. 2006;9:13-15. http://www.harmo.org/Conferences/ Proceedings/_Crete/publishedSections/p139.pdf, accessed 15.11.2015.

[11] Keder J. Adaptation of the Czech regulatory dispersion model for odour dispersion calculation. Chem Eng Transaction. 2008;15:17-22. http://www.aidic.it/cet/08/15/003.pdf, accessed 15.11.2015.

\title{
MODELOWANIE EMISJI Z DUŻYCH BIOGAZOWNI
}

\author{
${ }^{1}$ Katedra Fizyki, Uniwersytet Hradec Králové, Hradec Králové, Czechy \\ ${ }^{2}$ EMPLA, Hradec Králové, Czechy \\ ${ }^{3}$ Český hydrometeorologický ústav, Praha, Czechy \\ ${ }^{4}$ IDEA-ENVI, Valašské Meziříčí, Czechy \\ ${ }^{5}$ Samodzielna Katedra Biotechnologii i Biologii Molekularnej, Uniwersytet Opolski, Opole, Polska
}

\begin{abstract}
Abstrakt: Głównym celem wskazanym w „Wytycznych dla rozwoju biogazowni rolniczych w Polsce w latach 2010-2020" jest budowa biogazowni rolniczych przetwarzających zasoby biomasy w odpowiednich dla gminy warunkach. W Czechach produkuje się około 6,5\% energii ze źródeł odnawialnych. Biogazownie, w przeciwieństwie do elektrowni słonecznych i wiatrowych, pracują stabilnie przez cały rok. Biomasa powinna być kluczowym źródłem realizacji zobowiązań czeskich wobec UE, w ramach których przyjęto produkcję $13 \%$ energii ze źródeł odnawialnych w 2020 roku. Dotychczasowe doświadczenia z działającymi 317 biogazowniami rolniczymi wykazały, że istnieją poważne problemy $\mathrm{z}$ właściwym ulokowaniem nowo zaprojektowanych biogazowni. Czesko-polskie tereny przygraniczne to przede wszystkim płaski, zalesiony obszar rekreacyjny. Dlatego też program SYMOS'97 (wersja 2013), dostosowany do modelowania dyspersji zapachu z dużych źródła rolniczych, jest odpowiedni do oceny wpływu biogazowni na tym obszarze. Uzasadnione jest szkolenie studentów w zakresie obsługi tego programu. Z tego powodu studenci z Uniwersytetu w Hradec Kralove i z Uniwersytetu Opolskiego, w ramach wymiany akademickiej i staży zawodowych, zapoznają się z zasadami działania i technologiami stosowanymi w biogazowni oraz poznają środowiska matematycznego i statystycznego modelowania rozprzestrzeniania się emisji z dużych źródeł przemysłowych i rolniczych. W artykule zaprezentowano propozycję treści kształcenia w tej dziedzinie zawodowej.
\end{abstract}

Słowa kluczowe: biogaz, odór, SYMOS’97 